mittee which consider and advise on applications for research grants provided by the M.R.C. In addition a joint committee of the Medical Research Council and the Cancer Research Campaign advises both bodies on applications for support. New appointments to these boards and committees from 1 September are given below.

Biological Research Board.-Professor R. R. Porter, F.R.S., Professor R. Whittam, F.R.S., Dr. R. Blowers, Professor S. Cohen, Professor E. W. Horton, Dr. Helen Muir.

B.R.B. Grants Committees.-Grants Committee 1 : Dr. R. Blowers, Dr. D. M. Blow, F.R.S., Professor S. Cohen, Professor K. A. Porter. Grants Committee 2: Professor E. W. Horton, Professor

J. F. Mitchell, Professor P. J. Randle.

Clinical Research Board (in consultation with the Health Departments).--Professor I. R. C. Batchelor, Professor A. C. Dornhorst, Professor A. Goldberg, Dr. A. F. Lever, Professor J. N. Walton.

C.R.B. Grants Committees.-Grants Committee 1: Professor A. Goldberg, Dr. D. T. Baird, Professor J. R. Batchelor, Mr. J. I. Burn, Dr. A. F. Lever, Professor S. J. G. Semple. Grants Committee 2: Professor J. N. Walton, Professor R. Hoffenberg, Dr. J. F. Nunn.

Tropical Medicine Research Board.-Dr. B. A. Newton, Professor W. Peters, Professor J. K. G. Webb.

M.R.C./Cancer Research Campaign Committee for Jointly Supported Institutes (in consultation with the Cancer Research Campaign). -Dr. J. Cairns, Professor M. A. Epstein, Dr. J. B. Gurdon, F.R.S.

\section{Public Health Laboratory Service Board}

The headquarters office of the Public Health Laboratory Service Board has moved to new premises at Colindale Hospital. The new address is Public Health Laboratory Service Board, Lower Entrance, Colindale Hospital, Colindale Avenue, London N.W.9 5EQ, phone 01-205 1295.

\section{Injuries to Unborn Children}

Representatives of all the royal colleges, most learned faculties and societies, the defence unions, and the B.M.A. met on 25 July to discuss the Law Commission's Working Paper No. 47 on Injuries to Unborn Children (see B.M.f., 27 January, p. 191). The initiative of the Law Commission in attempting to clarify the legal position in this difficult field and its desire to discuss possible legislation with the medical profession was welcomed. Public interest had arisen from the hope that a child born with a handicap would receive compensation. The recent thalidomide disaster showed that a child injured before birth from the effect of treatment given to the mother during pregnancy had at present no certain means of receiving compensation. A report of the meeting has just been issued, and the main conclusions agreed were as follows:

A child born alive should have a right of action, accruing at birth, in respect of injury either sustained by it after conception and before birth, or resulting from injury sustained by its mother during pregnancy due to the fault of a third party. The child should not have the right of action against its own mother. It should be a defence to an action brought by the child for antenatal injury that a medical practitioner acted in good faith and in accordance with accepted practice in the discharge of his prior duty towards the mother, having due regard to the unborn child, in carrying out any treatment or giving any advice.

\section{Symposium on Population Control}

A symposium on "Population Control" under the chairmanship of Sir John Peel will bc held at B.M.A. House, London, on Friday, 19 October from 2.30 to 5.30 p.m. Details may be obtained from the Secretary of the Board of Science and Education, B.M.A. House, Tavistock Square, London WC1H 9JP, and the programme is published on page xiv.

\section{Abortion Act}

The secretary of State for Social Services has decided not to give further approval under the Abortion Act to three nursing homes whose present approval expires in September. They are the Maryland Clinic, Halesowen, Worcs, Leigham (Private) Clinic, London S.W.16, and the Hampstead Nursing Home, London N.W.6.

\section{COMING EVENTS}

"Orthopaedics and General Practice-Joint Management."-Weekend meeting, 27-28 October, Epsom Postgraduate Medical Centre. Details and programme from the organizer, Medical Library, Epsom District Hospital, Dorking Road, Epsom, Surrey. (Tel. Epsom 26100, extn. 429.)

2nd Bioengineering Conference and Exhibition.-20-25 November, Milan. Details from the secretary, Federation of Scientific and Technical Associations, Piazzale R. Morandi 2, 20121 Milan, Italy.

Centre for Postgraduate Psychiatry, Birmingham.-Details of the programme of lectures and open postgraduate meetings, 1973-4, are obtainable from the secretary, Charles Burns Clinic and Uffculme Clinic, Queensbridge Road, Moseley, Birmingham B13 8QD. (Tel. 021-449 4011.)

\section{SOCIETIES AND LECTURES}

For attending lectures marked a fee is charged made first to the institution concerned.

Monday, 1 October

CHADWICR TRUST.-At Royal Society of Health London S.W.1, 5.15 p.m., Sir Selwyn SelwynClarke: "Civilization-Bane or Boon."

LONDON UNIVERSITY.-At Chester Beatty Research Institute, S.W.3, 5.30 p.m., Dr. H. D. Sui (Massachusetts): Interaction of Hyperthermia and
Radiation in Destruction of Tumour.

Tuesday, 2 October

Royal Army Medical College.-5 p.m., Professor A. L. Cochrane: Effectiveness and Efficiency.

Wednesday, 3 October

ROYAL FREe HOSPITAL.— 5.15 p.m., lecture by Dr. A. Doyle (Australia)

T. MARY'S HoSPITAL, London W.2.-7 p.m., Dr.

\section{B.M.A. NOTICES}

\section{Diary of Central Meetings}

OCTOBER

2 Tues. Hospital Junior Staffs Group Council, 10.15 a.m

2 Tues. Working Party on Services for the Elderly (Board of Science and Education), 11.30 a.m.

3 Wed. Council, 10 a.m.
5 Fri. Panel on Health Care Teams (Board of $5 \mathrm{Fri}$ Science and Education), $9.30 \mathrm{a.m}$.

5 Fri. Diseases of the Chest Group Committee, 2 p.m.

11 Thurs. Organization Committee, 11 a.m.

11 Thurs. Armed Forces Committee, 2 p.m.

17 Wed. Occupational Health Committee, 10.30 a.m.

17 Wed. Private Practice Committee, 10.30 a.m.

18 Thurs. Executive Subcommittee (C.C.H.M.S.)

18 Thurs. General Medical Services Committee,

19 Fri. Public Health Committee, 9.30 a.m. 19 Fri. Public Health Committee, 9.30 a.m.
19 Fri. Consultant Contract Working Party

19 Fri. Chairman's Subcommittee (Joint Consultants Committee) (at Royal College sultants Committee) (at Royal Colleg

19 Fri. Ophthalmic Group Committee, 2 p.m.

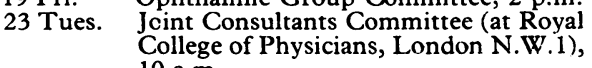
10 a.m.

24 Wed. Central Ethical Committee, 10.30 a.m.

24 Wed. Committee on the E.E.C., 2 p.m.

26 Fri. Venereologists Group Committee,

2 p.m.
Working Party on Services for the

Working Party on Services for the
Elderly (Board of Science and Education), 3.30 p.m.

Branch and Division Meetings to be Held

Members proposing to attend meetings marked* are asked to notify in advance the honorary secretary

Armagh and West Down Division.-At postgraduate medical centre, Craigavon Area Hospital, Tuesday, 2 October, 8.30 p.m., clinical meeting.

Brighton and Mid-Sussex Division.-At Postgraduate Medical Centre, Elm Grove, Brighton, Tuesday, 2 October, 8.15 p.m., a.g.m.

Buckinghamshire Division.-At Stoke Mandeville Hospital, Saturday, 6 October, 8 p.m., deville Hospital, Saturday, 6 October,

sparkling wine party. Guests are invited.*
Durham Division.-At Dryburn Hospital, Durham Division.-At Dryburn Hospital,
Monday, 1 October, 7.30 for 7.45 p.m., annual Monday, 1 October, 7.30 for 7.45 p.m., annual
dinner and general meeting, Mr. P. R. Kaimdinner and general meeting, Mr. P. R. Kaim

\section{APPOINTMENTS}

Wessex Regional Hospital Board.-Dr. Judith M. Darmady (consultant paediatrician, North Hampshire group); Dr. J. F. Hallpike (consultant neurologist, Southampton University group)

\section{Corrections}

Conference of Royal Colleges and Faculties in Scotland

We have been asked to correct the title of Professor Richard Scott, one of the signatcries to the letter of the title above (22 September, p. 641). Professor Scott is chairman, Scottish Council, Royal College of General Practitioners.

\section{Notice to Authors}

When original articles and letters for publication are not submitted exclusively to the British Medical fournal this must be stated. Accepted articles may subsequently be selected for publication in the North American monthly edition.

Correspondence on editorial business should be addressed to the Editor, British Medical fournal, B.M.A. House, Tavistock Square, London WC1H 9JR. Telephone: 01-387 4499. Telegrams: Aitiology, London, W.C.1.

Authors wanting reprints of their articles should notify the Publishing Manager, B.M.A. House, Tavistock Square, WC1H 9JR, on receipt of proofs.

(C) British Medical Journal 1973

All Rights Reserved. No part of this publication may be reproduced, stored in a retrieval system, or transmitted, in any form or by any means, electronic, mechanical, photocopying, recording or otherwise, without the prior permission of the Briiish Medical fournal. 